\title{
THE RIGHT TO FAMILY LIFE AND RELIGIOUS FREEDOM VERSUS THE STATES`INTERESTS
}

\author{
Bianca-Codruța BĂRA \\ West University Timișoara, Romania \\ bara.bianca92@yahoo.com
}

\begin{abstract}
The right to family life and religious freedom rejoice an universal recognition. The right to family life involves the prerogative of exercising parental authority in accordance with the religious beliefs of the parents. The right of parents to decide on behalf of their children is not an absolute one. Interference by the states must justify a legitimate aim and must be proportionate to that purpose. The states have to maintain a balance between the right to family life and religious freedom and its interests in safeguarding the lives and health of its citizens. The difficulty of maintaining this balance was also found in the jurisprudence of the courts. The most common cases arose as a result of the refusal of parents who belonged to the Jehovah's Witnesses religion to allow blood to be transfused for their children, risking their lives. Although the courts have explicitly recognized the right of parents to raise their children in accordance with their beliefs, they have shown that rescuing life and ensuring the physical and mental integrity of children are issues of national concern, so that the rapid intervention of public authorities, when these values are jeopardized, becomes not only a right of the state but also an obligation.
\end{abstract}

\section{Keywords: right to family life, religious freedom, states, balance.}

\section{Introduction}

The right to family life is recognized by important international documents, such as the Universal Declaration of Human Rights, the International Covenant on Civil and Political Rights and the European Convention on Human Rights.

According to article 16 (3) of the Universal Declaration of Human Rights: "the family is the natural and fundamental group unit of society and is entitled to protection by society and the State" [1].

Article 17 (1) of the International Covenant on Civil and Political Rights states that: "no one shall be subjected to arbitrary or unlawful interference with his privacy, family, home or correspondence, nor to unlawful attacks on his honor and reputation" [2]. In the same way, the
European Convention on Human Rights, in article 8, stipulates that: "everyone has the right to respect for his private and family life, his home and his correspondence. There shall be no interference by a public authority with the exercise of this right except such as is in accordance with the law and is necessary in a democratic society in the interests of national security, public safety or the economic well being of the country, for the prevention of disorder or crime, for the protection of health or morals, or for the protection of the rights and freedoms of others" [3].

The religious freedom is also protected by numerous international documents. For example, the first article of the Declaration on the Elimination of All Forms of Intolerance and of Discrimination Based on 
Religion or Belief states that "everyone shall have the right to freedom of thought, conscience and religion. This right shall include freedom to have a religion or whatever belief of his choice, and freedom, either individually or in community with others and in public or private, to manifest his religion or belief in worship, observance, practice and teaching" [4].

The First Amendment of the United States Constitution guarantees the freedom of religion, stating that "congress shall make no law respecting an establishment of religion, or prohibiting the free exercise thereof" [5].

\section{The battle between fundamental rights and freedoms}

Both the right to private life and the religious freedom were invoked to support the parents' refusal to allow their children to undergo medical procedures, particularly blood transfusions.

States have the difficult task of maintaining a balance between the parental authority and the protection of the fundamental values of any society in which life occupies a dominant position. Protection of this value becomes a matter of national interest.

The common-law jurisprudence highlighted the difficulty of maintaining this balance in many cases that arose as a result of parents' refusal to blood transfusion for patients belonging to the Jehovah's Witnesses religion.

Such a case [6] was analyzed by the Illinois Supreme Court, which was called to decide upon the case of a newborn, diagnosed with fetal erythroblastosis. Despite the fact that doctors explained that in the absence of blood transfusions there were extremely high chances of causing the child's death, parents refused this medical procedure, invoking the prohibition imposed by the religion they embraced, namely the Jehovah's Witnesses. Because of this refusal, a lawsuit was promoted in order to carry out blood transfusions so that the life of the child was saved. The court decided to place the child in the custody of the Probation Service so that medical intervention can be granted a valid consent [7].

The Court recognized that this case represents a real challenge for the state authorities, which have to maintain a balance between religious freedom and the parental authority, on the one hand, and between the obligation to take urgent measures to safeguard the fundamental interests of any societies, on the other hand. The court stated that saving lives and ensuring the physical and mental integrity of children are issues of national interest, so that the rapid intervention of public authorities, if these values are jeopardized, becomes not only a state right but also an obligation [8]. According to the Court, the refusal of parents to express the necessary consent to a medical procedure of this kind, the delay of which determines the imminence of the loss of the child's life, justifies an urgent intervention by the state.

The same arguments were invoked in the case [9] of a minor who suffered from leukemia, whose parents denied chemotherapy, although specialists shown that the treatment would have led to an evolution for his health. The parents argued that their decision is an expression of constitutional right to family life and the right for parents to decide which treatment is appropriate for the minor [10].

The Court ruled that states can intervene when parents refuse to administer the only type of medical treatment that could save the life of their child. Parental authority does not give parents a right to life and death on their children. Courts should refrain from parents' decision to subject their children to various medical interventions when these interventions do not have a decisive influence on the health. The situation is different when, in the absence of treatments or medical interventions, there is a serious risk of death. The Court reaffirmed that when the well-being of the child is endangered, the need to ensure a harmonious physical and psychological development of the child will be more important than the parental rights [11]. 
Four important elements were analyzed in the context of the battle of these two fundamental rights and freedoms. It was considered that acute lymphocytic leukemia is fatal for children if not treated, that the only available medical treatment that offered hope for healing was chemotherapy, that the risks of the treatment were minimal compared to the consequences of letting the disease untreated and finally that parents did not want to continue with the chemotherapy of the baby, regardless of the consequences [12].

A similar cause was brought before the Romanian courts [13]. A minor was diagnosed with right kidney neuroblastoma, a diagnosis after which surgery was performed and a line I chemotherapy was performed. After a series of medical interventions, the specialists confirmed the presence of pulmonary metastases, meaning that resumption of chemotherapy was recommended. Despite numerous efforts by doctors and public institutions to persuade parents to subject the patient to chemotherapy, they refused, citing both distrust in the medical system and lack of material resources. The court acknowledged that the right of the defendants to family life is guaranteed by the Constitution of Romania, but also by the article 8 of the European Convention on Human Rights. One aspect of family life is the unhindered exercise of parental authority. According to the court, "law protects family relationships against public authorities' interventions, unless the intervention is provided by the law and represents a necessary measure for the national security, the public security, the country's economic well-being, the defense of order and the prevention of criminal deeds and the protection of health, morals, rights and freedoms of others" [14].

The Romanian court acknowledged that the child's subjection to chemotherapy, despite the explicit refusal of parents, is an interference with the right to family life but showed that this interference is "absolutely necessary in a democratic society which has the obligation to respect the rights of all its citizens and to take measures to protect them, especially for those who, because of their young age, are unable to express their valid consent" [15].

\section{Conclusions}

Any democratic society must respect the right to family life and religious freedom, which outline the private component of the existence of people. Family is a fundamental pillar of any society, with important implications not only in social, but also economic, political and religious areas. Protecting it must represent a constant concern of the public authorities and institutions.

The protection of family concerns not only the parents, but also the children. The exercise of parental rights has to be done only in the best interests of the children. When parents risk to endanger the physical and mental well-being of children through the decisions they make, even if they are founded on religious grounds, the intervention of the authorities is fully justified. The state must compensate the vulnerability of the children, resulting from their emotional and economic dependence on their parents.

\section{References}

[1] http://www.un.org/en/universal-declaration-human-rights/

[2] http://www.ohchr.org/en/professionalinterest/pages/ccpr.aspx

[3] http://www.echr.coe.int/Documents/Convention_ENG.pdf

[4] http://www.un.org/documents/ga/res/36/a36r055.htm

[5] https://www.law.cornell.edu/constitution/first amendment

[6] Prince v. Massachusetts, 321 U.S. 158 (1944).

[7] https://supreme.justia.com/cases/federal/us/321/158/case.html 
[8] Ibidem.

[9] Custody of a minor, 375 Mass. 733 (1978).

[10] https://www.leagle.com/decision/19781108375mass73311029

[11] Ibidem.

[12] Ibidem.

[13] The case no. 1115/286/2017 of the Court of first instance of Răducăneni.

[14] http://www.rolii.ro/hotarari/5a1f758be49009fc28000029

[15] Ibidem. 